\title{
S1PR1 wt Allele
}

National Cancer Institute

\section{Source}

National Cancer Institute. S1PR1 wt Allele. NCI Thesaurus. Code C102499.

Human S1PR1 wild-type allele is located in the vicinity of $1 \mathrm{p} 21$ and is approximately $5 \mathrm{~kb}$ in length. This allele, which encodes sphing osine 1-phosphate receptor 1 protein, is involved in sphing olipid binding. 